\title{
Multidrug resistant Kluyvera ascorbata septicemia in an adult patient: a case report
}

\author{
Shannon Moonah*, Kavita Deonarine and Clyde Freeman
}

\begin{abstract}
Introduction: Kluyvera ascorbata has become increasingly significant due to its potential to cause a wide range of infections, as well as its ability to transfer gene encoding for CTX-M- type extended spectrum B-lactamases (ESBLs) to other Enterobacteriaceae.

Case presentation: We report the case of a 64-year-old African-American male diagnosed with severe sepsis due to a multidrug resistant Kluyvera ascorbata, which was isolated from his blood. He was treated with meropenem and had a favorable outcome.
\end{abstract}

Conclusion: To the best of our knowledge, this is the first case report of a multidrug resistant Kluyvera ascorbata isolated from the blood in an adult patient with sepsis.

\section{Introduction}

Kluyvera ascorbata is a gram negative microorganism belonging to the family Enterobacteriaceae. Although it causes infections infrequently, it is responsible for causing a wide range of infections including severe sepsis $[1,2]$. It is believed to be the source of genes encoding CTX-M-type extended spectrum B-lactamases (ESBLs) and it has the ability to transfer these genes to other Enterobacteriacae [3]. Only three cases of $K$. ascorbata isolated from the blood of adult patients have been reported [4-6]. We report what we believe to be the first case of a multidrug resistant $K$. ascorbata isolated from the blood of an adult patient with sepsis.

\section{Case presentation}

A 64-year-old African-American man with a past medical history of hypertension, type 2 diabetes mellitus, bilateral above knee amputation, prostate cancer post radical prostatectomy in 1999, quadraparesis secondary to cervical spine fracture of $\mathrm{C} 4$, neurogenic bladder with an indwelling suprapubic catheter and recurrent urinary tract infections was transferred from a nursing home to Howard University Hospital in June 2009 because of lethargy, fever and low blood pressure (BP). There was no

* Correspondence: smoonah@howard.edu

1 Department of Medicine, Howard University Hospital, 2041 Georgia Avenue NW, Washington DC, 20060, USA

Full list of author information is available at the end of the article history of cough, chest pain, vomiting, diarrhea or headache.

His admitting temperature was $101.4^{\circ} \mathrm{F}$ and blood pressure $61 / 34 \mathrm{mmHg}$, which responded to intravenous fluid boluses. His initial white blood count (WBC) was $14.4 \times 10^{9} / \mathrm{L}$. His chest radiograph showed mild left lung base ateclectasis, but the rest of the lung fields were clear. Urinalysis showed large amounts of red cells, white cells and numerous bacteria. He was admitted to the medical intensive care unit (MICU) and started empirically on vancomycin and levofloxacin.

Over the following five days his condition improved, with normalization of his mental status, temperature, BP and WBC. His initial blood culture bottle grew grampositive cocci, identified as Coagulase-negative staphylococci, thought to be a contaminant. Both urine cultures were sterile.

He was transferred to the medical floor for further care. 24 hours later he developed a low grade temperature of $95.9^{\circ} \mathrm{F}$, his BP decreased to a systolic of $75 \mathrm{mmHg}$ and WBC increased to $13 \times 10^{9} / \mathrm{L}$. There was no change in his mental status. He was given boluses of intravenous fluids. Meropenem was immediately added to his antibiotic regimen. A gram stain of his repeat blood culture revealed gram negative rods which were later identified as $K$. ascorbata. The isolate was susceptible to amikacin, tobramycin and imipenem, but resistant to ampicillin, piperacillin, cefazolin, cefuroxime, cefotaxime, ceftriax- 
one, ceftazidime, aztreonam, ciprofloxacin and levofloxacin. Species identification and antimicrobial susceptibility testing was performed using Microscan panels (Dade Behring). He was placed on contact isolation and levofloxacin was discontinued. Over the next five days he maintained a normal temperature, BP and WBC. Repeat blood cultures and a urine culture were negative for growth. He was discharged back to the nursing home after 13 days of hospitalization for continued care.

\section{Discussion}

Kluyvera spp was first described in 1936 by Kluyver and van Neil [7], but it was not until 1981 that it was defined completely using molecular characterization [8]. Four species are described: $K$. cryocrescens, $K$. ascorbata, $K$. georgiana, and K. cochleae. K. ascobata causes a wide range of infectious diseases in different age groups and of varying severity $[1,2,9]$.

Only three cases isolating $K$. ascobata from the blood of adult patients with sepsis have been reported. In all three cases the organism was susceptible to third generation cephalosporins (Table 1). To the best of our knowledge, this is the first case report describing an isolate of multidrug resistant $K$. ascorbata from the blood of an adult patient with sepsis. The isolate was resistant to third generation cephalosporins and fluoroquinolones. In addition to its ability to cause severe sepsis, we also report its multidrug resistant potential. This must be considered when choosing appropriate antimicrobial therapy. We believe that the prompt administration of a carbapenem resulted in a favorable outcome for the patient.

ESBLs are enzymes produced by certain types of bacteria such as E. coli. They mediate resistance to extendedspectrum cephalosporins (e.g. ceftriaxone) but do not affect carbapenems (e.g. meropenem). Molecular and genetic evidence indicates that CTX-M-type ESBLs found in E. coli and other Enterobacteriaceace evolved from chromosomal genes from $K$. ascobata. In the past decade CTX-M enzymes have become the most preva-

Table 1: Summary of the four reported Kluyvera ascorbata cases isolated from the blood of adult patients

\begin{tabular}{|c|c|c|c|c|c|c|}
\hline \multirow[t]{2}{*}{ Ref. } & \multirow[t]{2}{*}{ Age/sex } & \multirow{2}{*}{$\begin{array}{l}\text { Past medical } \\
\text { history }\end{array}$} & \multicolumn{2}{|c|}{ Antimicrobial susceptibility } & \multirow[t]{2}{*}{ Treatment } & \multirow[t]{2}{*}{ Outcome } \\
\hline & & & Susceptible & Resistant & & \\
\hline [4] & $72 / \mathrm{M}$ & $\begin{array}{l}\text { Liver cirrhosis, } \\
\text { Hepatocellular } \\
\text { carcinoma, } \\
\text { Hepatitis C }\end{array}$ & $\begin{array}{l}\text { Amoxicilin/Clavulanate } \\
3^{\text {rd }} \text { generation } \\
\text { cephalosporins } \\
\text { Aminoglycosides } \\
\text { Ciprofloxacin } \\
\text { Imipenem } \\
\text { Aztreonam }\end{array}$ & $\begin{array}{l}\text { Ampicillin } \\
\text { Ticarcillin } \\
\text { Cephalothin } \\
\text { Cefuroxime }\end{array}$ & Cefotaxime & Recovered \\
\hline [5] & $23 / \mathrm{M}$ & $\begin{array}{l}\text { Liver cirrhosis, } \\
\text { Hepatitis B }\end{array}$ & $\begin{array}{l}\text { Amoxicilin/ } \\
\text { Clavulanate } \\
\text { Piperacillin } \\
\text { Ceftriaxone } \\
\text { Gentamicin } \\
\text { Ciprofloxacin }\end{array}$ & $\begin{array}{l}\text { Ampicillin } \\
\text { Cefazolin } \\
\text { Ticarcillin }\end{array}$ & Ceftriaxone & Recovered \\
\hline [6] & $57 / F$ & $\begin{array}{l}\text { Colon } \\
\text { adenocarcioma, } \\
\text { Chemotherapy, } \\
\text { Neutropenia }\end{array}$ & $\begin{array}{l}\text { Aminoglycosides } \\
3^{\text {rd }} \text { generation } \\
\text { cephalosporins } \\
\text { Flouroquinolones } \\
\text { Ureidopenicillins }\end{array}$ & $\begin{array}{l}\text { Ampicillin } \\
\text { Amoxicilin/ } \\
\text { Clavulanate } \\
2^{\text {nd }} \text { generation } \\
\text { cephalosporins } \\
\text { Cotrimazole }\end{array}$ & $\begin{array}{l}\text { Ceftazidime } \\
\text { Amikacin }\end{array}$ & Expired \\
\hline $\begin{array}{l}\text { Present } \\
\text { report }\end{array}$ & $64 / M$ & $\begin{array}{l}\text { Neurogenic } \\
\text { bladder with an } \\
\text { indwelling } \\
\text { suprabupic } \\
\text { catheter, } \\
\text { Recurrent urinary } \\
\text { tract infections }\end{array}$ & $\begin{array}{l}\text { Amikacin } \\
\text { Tobramycin } \\
\text { Imipenem }\end{array}$ & $\begin{array}{l}\text { Ampicillin } \\
\text { Aztreonam } \\
\text { Ceftazidime } \\
\text { Cefotaxime } \\
\text { Cetftriaxone } \\
\text { Cefuroxime } \\
\text { Cefazolin } \\
\text { Ciprofloxacin } \\
\text { Levofloxacin } \\
\text { Piperacillin }\end{array}$ & Meropenem & Recovered \\
\hline
\end{tabular}


lent ESBLs and CTX-M producing E. coli is becoming a major public health problem. This rise will result in the narrowing of effective options to treat infections caused by these organisms. There will likely be increased usage of carbapenems, thus generating further selective pressure for carbapenemases and carbepenem resistance in the future $[3,10-12]$.

\section{Conclusion}

K. ascorbata is an infrequent cause of infection, but can result in severe sepsis. Clinicians should be aware of its infectious and multidrug resistant potential as early and appropriate treatment can result in recovery.

\section{Consent}

Written informed consent was obtained from the patient for the publication of the case report and any accompanying images. A copy of the written consent is available for review by the Editor-in-Chief of this journal.

\section{Competing interests}

The authors declare that they have no competing interests.

\section{Authors' contributions}

$S M, K D$, and CF were involved in the direct care of the patient, and contributed to the literature search, data collection, data analysis, and manuscript preparation. All authors have read and approve of the submitted manuscript.

\section{Author Details}

Department of Medicine, Howard University Hospital, 2041 Georgia Avenue NW, Washington DC, 20060, USA

Received: 3 December 2009 Accepted: 29 June 2010

Published: 29 June 2010

\section{References}

1. Sarria JC, Vidal AM, Kimbrough RC: Infections caused by Kluyvera species in humans. Clin Infect Dis 2001, 33:E69-74.

2. Carter JE, Evans TN: Clinically significant Kluyvera infections: a report of seven cases. Am J Clin Pathol 2005, 123:334-338.

3. Muller-Pebody B, Lillie M, Johnson AP: Isolation and antimicrobial sensitivities of Kluyvera spp. from humans in England, Wales and Northern Ireland, 2005-2006. Int J Antimicrob Agents 2007, 30:371-372.

4. Padilla E, Tudela P, Giménez M, Gimeno JM: Kluyvera ascorbata bacteremia. Med Clin (Barc) 1997, 108:479.

5. Oteo J, Gómez-Garcés JL, Alós Jl: Acute cholecystitis and bacteremia caused by Kluyvera ascorbata in a cirrhotic patient. Clin Microbiol Infect 1998, 4:113-115.

6. Linares P, Castañón C, Llano C, Diz P, García-Palomo A, González LM, Fernández-Natal I: Bacteremia by Kluyvera ascorbata in a patient with neutropenia and fever. Enferm Infecc Microbiol Clin 2000, 18:48-49.

7. Kluyver AJ, van Neil CB: Prospects for a natural system of classification of bacteria. Zentralbl Bakteriol Parasitenkd Infektionskr Hyg Abt II 1936, 95:369-403.

8. Farmer JJ, Fanning GR, Huntley-Carter GP, Holmes B, Hickman FW, Richard C, Brenner DJ: Kluyvera, a new (redefined) genus in the family Enterobacteriaceae:identification of Kluyvera ascorbata sp. nov. and Kluyvera cryocrescens sp. nov. in clinical specimens. J Clin Microbiol 1981, 13:919-933.

9. Carter JE, Laurini JA, Mizell KN: Kluyvera infections in the pediatric population. Pediatr Infect Dis J 2008, 27:839-841.

10. Humeniuk C, Arlet G, Gautier V, Grimont P, Labia R, Philippon A: Betalactamases of Kluyvera ascorbata, probable progenitors of someplasmid-encoded CTX-M types. Antimicrob Agents Chemother 2002, 46:3045-3049
11. Cantón R, Coque TM: The CTX-M beta-lactamase pandemic. Curr Opin Microbiol 2006, 9:466-475.

12. Denton M: Enterobacteriaceae. Int J Antimicrob Agents 2007, 29(Suppl 3):S9-S22.

doi: 10.1186/1752-1947-4-197

Cite this article as: Moonah et al., Multidrug resistant Kluyvera ascorbata septicemia in an adult patient: a case report Journal of Medical Case Reports 2010, 4:197
Submit your next manuscript to BioMed Centra and take full advantage of:

- Convenient online submission

- Thorough peer review

- No space constraints or color figure charges

- Immediate publication on acceptance

- Inclusion in PubMed, CAS, Scopus and Google Scholar

- Research which is freely available for redistribution

Submit your manuscript at www.biomedcentral.com/submit
Ciomed Central 